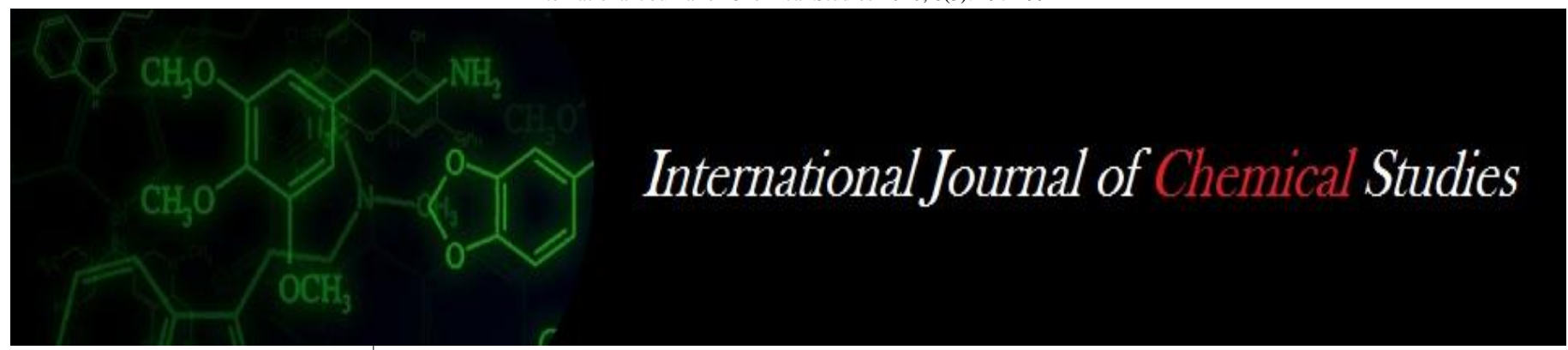

P-ISSN: 2349-8528

E-ISSN: 2321-4902

www.chemijournal.com

IJCS 2020; 8(3): 197-199

(C) 2020 IJCS

Received: 07-03-2020

Accepted: 09-04-2020

\section{Saket Dubey}

Ph.D. Scholar (Fruit Science),

Department of Fruit Science

(IGKV), Raipur, Chhattisgarh,

India and Subject Matter

Specialist (Horticulture), KVK,

Mahasamund, Chhattisgarh,

India

Ghanshyam D Sahu

Scientist, Department of Fruit

Science (IGKV), Raipur,

Chhattisgarh, India

\section{Vijay Kumar}

Professor and Head, Department of Fruit Science (IGKV), Raipur,

Chhattisgarh, India

\section{Ravi R Saxena}

Professor, Department of

Agricultural Statistics (IGKV),

Raipur, Chhattisgarh, India

\section{Debashish Hota}

Ph.D. Scholar, Department of

Fruit Science (IGKV), Raipur,

Chhattisgarh, India
Corresponding Author: Saket Dubey

Ph.D. Scholar (Fruit Science) and Subject Matter Specialist (Horticulture), KVK,

Mahasamund, Chhattisgarh, India

\section{Effect of plant growth regulators on chemical quality of papaya (Carica papaya) cv. Red Lady}

\author{
Saket Dubey, Ghanshyam D Sahu, Vijay Kumar, Ravi R Saxena and \\ Debashish Hota
}

DOI: https://doi.org/10.22271/chemi.2020.v8.i3c.9222

\begin{abstract}
The present investigation has been conducted for two consecutive years (2018-19 and 2019-20) to determine the effect of various phyto bio regulators on chemical quality of papaya (Carica papaya) cv. Red Lady in a randomized block design using factorial arrangement with 11 treatments and 03 replications. The treatment consists of two concentrations i.e. $100 \mathrm{ppm} \& 150 \mathrm{ppm}$ of various phyto bio regulators which includes Naphthalene acetic acid (100 and $150 \mathrm{ppm})$, Gibberellic acid (100 and 150 ppm), Benzyl adenine (100 and $150 \mathrm{ppm})$, Ethrel (100 and $150 \mathrm{ppm}$ ) and 2,3,5-Triiodo benzoic acid (100 and $150 \mathrm{ppm}$ ). The study revealed that phyto bio regulators significantly affect the chemical quality of papaya fruits. The ascorbic acid was found to be highest in $150 \mathrm{ppm}$ of Gibberellic acid while Ethrel (150 $\mathrm{ppm}$ ) recorded significantly highest value of TSS, total sugar, reducing sugar, non-reducing sugar, sugar: acid ratio and lowest value of titrable acidity.
\end{abstract}

Keywords: Papaya, phyto growth regulators and chemical quality

\section{Introduction}

The India is blessed with variety of fruit crops to fulfil the nutritional and medicinal needs of the people. Out of these fruit crops, Papaya (Carica papaya) is one the important fruit crop, which is commonly known as "wonder fruit" of tropical and subtropical regions (Radha and Mathew, 2007) ${ }^{[24]}$ by virtue of it's highly remunerative, nutritional and medicinal properties. Moreover, it is easy to cultivate that can be grown throughout the year and poses quick returns (Drew et al. 1998) ${ }^{[6]}$.

The plant hormones (or phytohormones) are the naturally producing organic substance in the plant that are produced in minute quantities and regulates the growth and other physiological functions of a plant. Hence, such chemical substances have proven to be an important component of modern fruit production technology both for improving the quantity as well as quality of fruit crops (Jain and Dashora, 2011) ${ }^{[20]}$. It alters the parameters like vegetative growth (Hota et al., 2017a ${ }^{[13]}$; Priyadarshi et al., $2017^{[23]}$ ), fruit set (Hota et al., 2017b) ${ }^{[15]}$, fruit drop (Hota et al., 2017c) [16], yield attributing parameter (Hota et al., 2017d [18], Priyadarshi et al., 2018a ${ }^{[22]}$ ), physical parameters (Hota et al., 2017e) ${ }^{[19]}$, chemical parameters (Hota et al., $2018^{[14]}$, Priyadarshi et al., 2018b ${ }^{[21]}$ ) and physico-chemical parameters (Hota et al., 2017f) ${ }^{[17]}$. Since, such chemical products have various diverse affects, hence, it is used at particular stage of production cycle to get maximum benefit out of them (Hota et al., 2019) ${ }^{[12]}$. Moreover, with the advancement of technology, these chemicals can be supplied exogenously, in both natural and synthetic form (as their chemical analogs, hormone releasing agents, hormone sensitivity altering agents and hormone synthesis inhibitors (Hajam et al., 2017) ${ }^{\text {9] }}$, in such a way that it can modify the plant production processes, thereby increasing the yield (Singh and Singh, 2009) ${ }^{[26]}$. Furthermore, the consumer acceptability of papaya fruits, largely depends on various physiochemical properties like TSS (Gaudence et al., 2019) ${ }^{[7]}$, besides affecting it's organoleptic value and shelf life (Vagadia et al., 2016) ${ }^{[27]}$. Considering this fact, the present investigation has been designed to determine the effect of various phyto bio regulators on qualitative aspect of papaya cv. Red Lady. 


\section{Materials and method}

The Mahasamund district of Chhattisgarh is located at $20^{\circ} 47^{\prime}$ to $21^{\circ} 31^{\prime} \mathrm{N}$ latitude and $82^{\circ} 00^{\prime}$ to $83^{\circ} 15^{\prime}$ longitude having sub humid climatic conditions with an average annual rainfall of $1200 \mathrm{~mm}$. The present investigation was conducted at Farm of Krishi Vigyan Kendra, Mahasamund for two consecutive years (2018-19 and 2019-20) in a moderately sloped land with appropriate drainage system.

The healthy, disease and pest free Red Lady seeds were raised in polybags $(12 \times 10 \mathrm{~cm}$ size $)$ filled with a mixture of Soil, Sand and Vermicompost. The polybags were regularly irrigated and utmost care of nursery plants is taken until they are ready for transplanting in the field. The experimental plants were planted at a distance of $2 \mathrm{mt}$.x $2 \mathrm{mt}$.and were cultivated adopting recommended package of practices. The experiment was designed in Randomized Block Design with three replications and 11 treatment combinations which were as follows: $\mathrm{T}_{0}$, Control (Water Spray); $\mathrm{T}_{1}$, Naphthalene acetic acid (NAA) 100 ppm; $T_{2}$, Naphthalene acetic acid (NAA) 150 ppm; $\mathrm{T}_{3}$, Gibberellic acid $\left(\mathrm{GA}_{3}\right) 100 \mathrm{ppm} ; \mathrm{T}_{4}$, Gibberellic acid $\left(\mathrm{GA}_{3}\right) 150 \mathrm{ppm} ; \mathrm{T}_{5}$, Benzyl adenine (BA) $100 \mathrm{ppm} ; \mathrm{T}_{6}$, Benzyl adenine (BA) 150 ppm; $\mathrm{T}_{7}$, Ethrel 100 ppm; T , Ethrel 150 ppm; $\mathrm{T}_{9}, 2,3,5$-Triiodo benzoic acid (TIBA) $100 \mathrm{ppm} ; \mathrm{T}_{10}$, 2,3,5-Triiodo benzoic acid (TIBA) $150 \mathrm{ppm}$.

The foliar spray of growth regulators was done at different time slots i.e. 45,75 and 125 days after transplanting. The solutions of different concentrations were sprayed to wet the whole plant with care to avoid its drooping on the soil surface. The data pertaining to quality parameters (Total Soluble Solids, Titrable Acidity, Ascorbic Acid, Sugar Acid Ratio and Sugars- Total, Reducing and Non-reducing) was recorded as per the methods suggested by Ranganna (1997) ${ }^{[25]}$ and was subjected to statistical analysis of variance as described by Gomez and Gomez (1984) ${ }^{[8]}$.

\section{Results and Discussion}

The phyto bio regulators pose significant effect on various chemical parameters of papaya fruit (Table-1). The significant maximum value of total soluble solids $\left(16.80^{\circ}\right.$ Brix $)$, total sugar $(9.79 \%)$, reducing sugar $(7.54 \%)$ and non-reducing sugar $(2.25 \%)$ as well as sugar acid ratio (79.76) along with lowest value of titrable acidity $(0.123 \%)$ were recorded in Treatment $\mathrm{T}_{8}$ i.e. $150 \mathrm{ppm}$ of ethrel. Further Treatment $\mathrm{T}_{4}$ i.e. $\mathrm{GA}_{3} 150 \mathrm{ppm}$ recorded maximum value (82.41) of ascorbic acid content in papaya fruits

The total soluble solid (TSS) was found to be highest for $\mathrm{T}_{8}$ treatment i.e. Ethrel $150 \mathrm{ppm}$. Since, the phyto bio regulators enhance the growth rate of plants, which causes higher metabolites accumulation besides increasing the conversion rate of starch into soluble sugars (Agrawal and Dikshit, 2010) [1]. This finding was in accordance with Hazarika et al. (2016) [10], where they had observed higher TSS with ethrel on papaya (Carica papaya) cv. Red lady.

The titrable acidity was significantly lowest in treatment $T_{8}$ i.e. Ethrel $150 \mathrm{ppm}$ and was highest for treatment $\mathrm{T}_{6}$ i.e. BA $150 \mathrm{ppm}$. Since, the benzyl adenine behaves as an antisenescence agent, thereby affects the various biochemical processes that are responsible for metabolic deterioration in the fruits (Bhardwaj et al. 2005) ${ }^{[2]}$.

For the various catabolic processes in fruits, organic acids acts as the necessary respiratory substrate (Chouksey et al., 2013) ${ }^{[5]}$, Hence, BA reduces the conversion of organic acids into sugar, thereby increasing it's concentration as compared to other phyto bio regulators. Canli et al., $2009^{[4]}$ had also observed the similar effect of benzyl adenine (BA) on titrable acidity of pear fruit (Pyrus communis). On the other hand, ethrel as fruit ripener, increases the metabolic deterioration processes of organic acids in the fruit. This finding was in accordance with Hazarika et al. (2016) ${ }^{[10]}$ and Yadav et al (2011) ${ }^{[28]}$, where both of them independently observed the same trend.

Table 1: Effect of phyto growth regulators on chemical parameters of fruits

\begin{tabular}{|c|c|c|c|c|c|c|c|}
\hline Treatment & $\begin{array}{c}\text { TSS } \\
\left({ }^{\circ} \text { Brix }\right)\end{array}$ & $\begin{array}{c}\text { Acidity } \\
(\%)\end{array}$ & $\begin{array}{c}\text { Ascorbic } \\
\text { acid } \\
(\mathbf{m g} / \mathbf{1 0 0} \\
\text { gm) }\end{array}$ & $\begin{array}{c}\text { Total } \\
\text { Sugar } \\
(\%)\end{array}$ & $\begin{array}{c}\text { Reducing } \\
\text { Sugar } \\
(\%)\end{array}$ & $\begin{array}{c}\text { Non- } \\
\text { reducing } \\
\text { Sugar } \\
(\%)\end{array}$ & $\begin{array}{l}\text { Sugar } \\
\text { Acid } \\
\text { ratio }\end{array}$ \\
\hline $\begin{array}{c}\mathrm{T}_{0} \text { Control } \\
\text { (Water) }\end{array}$ & 11.32 & 0.182 & 68.42 & 7.52 & 6.35 & 1.17 & 41.49 \\
\hline $\begin{array}{l}\mathrm{T}_{1} \mathrm{NAA} \\
100 \mathrm{ppm}\end{array}$ & 13.36 & 0.156 & 80.33 & 8.42 & 6.73 & 1.69 & 54.13 \\
\hline $\begin{array}{l}\mathrm{T}_{2} \text { NAA } \\
150 \mathrm{ppm}\end{array}$ & 13.96 & 0.151 & 80.81 & 8.67 & 6.88 & 1.79 & 57.68 \\
\hline $\begin{array}{c}\mathrm{T}_{3} \mathrm{GA} 3 \\
100 \mathrm{ppm} \\
\end{array}$ & 14.83 & 0.144 & 81.33 & 8.90 & 7.09 & 1.81 & 61.81 \\
\hline $\begin{array}{c}\mathrm{T}_{4} \mathrm{GA} 3 \\
150 \mathrm{ppm}\end{array}$ & 15.77 & 0.137 & 82.41 & 9.13 & 7.23 & 1.90 & 67.07 \\
\hline $\begin{array}{c}\mathrm{T}_{5} \mathrm{BA} 100 \\
\mathrm{ppm}\end{array}$ & 12.00 & 0.174 & 69.62 & 7.79 & 6.42 & 1.37 & 45.00 \\
\hline $\begin{array}{c}\mathrm{T}_{6} \mathrm{BA} 150 \\
\mathrm{ppm}\end{array}$ & 10.92 & 0.187 & 70.39 & 7.39 & 6.31 & 1.08 & 39.51 \\
\hline $\begin{array}{c}\mathrm{T}_{7} \text { Ethrel - } \\
100 \mathrm{ppm}\end{array}$ & 16.39 & 0.130 & 69.32 & 9.33 & 7.34 & 1.99 & 71.87 \\
\hline $\begin{array}{c}T_{8} \text { Ethrel - } \\
150 \mathrm{ppm}\end{array}$ & 16.80 & 0.123 & 69.43 & 9.79 & 7.54 & 2.25 & 79.76 \\
\hline $\begin{array}{l}\mathrm{T}_{9} \mathrm{TIBA} \\
100 \mathrm{ppm}\end{array}$ & 12.65 & 0.168 & 72.35 & 7.96 & 6.58 & 1.38 & 47.37 \\
\hline $\begin{array}{l}\text { T10 TIBA } \\
150 \mathrm{ppm} \\
\end{array}$ & 12.76 & 0.162 & 71.61 & 8.16 & 6.63 & 1.53 & 50.36 \\
\hline SEM & 0.15 & 0.007 & 0.36 & 0.10 & 013 & 0.16 & 3.51 \\
\hline $\mathrm{CD}$ at $5 \%$ & 0.43 & 0.022 & 1.05 & 0.30 & 0.39 & 0.48 & 10.36 \\
\hline
\end{tabular}

The ascorbic acid content was found to be highest for $\mathrm{T}_{4}$ treatment $\left(\mathrm{GA}_{3} ; 150 \mathrm{ppm}\right)$. The probable reason for such highest value with gibberellic acid may be attributed due to it's catalytic action of it's precursor glucose-6-phosphate or by arresting the activity of an enzyme ascorbic acid oxidase (which metabolizes ascorbic acid to dehydroascorbic acid) or both. This finding was in accordance with Hazarika et al. (2016) ${ }^{[10]}$ and Hetram (2017) ${ }^{[11]}$ on papaya fruit

The total sugar (TS), reducing and non-reducing sugar content was highest for $T_{8}$ treatment i.e. ethrel treated plants i.e. 150 ppm. This increase in sugar content might be due to the early ripening action of ethrel that enhances the action of various hydrolytic enzymes that participates in the respiration and carbon assimilation functions in the papaya, thereby breaking the complex polysaccharides compounds and organic acids into simple sugars (Singh and Singh, 2009) ${ }^{[26]}$. The increase in both reducing and non-reducing sugar might be also due to the same reasons. Similar results were also observed by other researchers (Biswas et al., 1988; Yadav et al., 2001) ${ }^{[3,28] .}$

The sugar acid ratio is the ratio between produced sugar and acid produced. The ratio was found to be highest in Treatment $\mathrm{T}_{8}$ (Ethrel $150 \mathrm{ppm}$ ) as the ethrel being a ripening hormone, converts starch to sugars through higher respiration and carbon assimilation activity. Further one of the reasons for lowest sugar acid ratio in $\mathrm{T}_{6}$ i.e. BA $150 \mathrm{ppm}$, is that it lowers the catabolic activity of polysaccharides, and increases the level of acid content. Similar findings was observed by Hazarika et al. (2016) ${ }^{[10] . ~}$ 


\section{Conclusion}

From the above investigation, it can be concluded that exogenous application of phyto bio regulators may acts as a useful tool not only for increasing the yield but also for improving the quality of fruits which helps in increasing consumer acceptability of produce. However, phyto bio regulators may be used judiciously to prevent any to prevent any ill effects, because of exogenous application of phyto bio regulators.

\section{References}

1. Agrawal S, Dikshit SN. Studies on the effect of phyto growth regulators on qualitative characters of sapota cv. Cricket Ball. Indian J. of Horti. 2010; 67:177-180.

2. Bhardwaj RL, Sen NL, Mukherjee S. Effect of benzyl adenine on physico-chemical characteristics and shelf life of mandarin cv. Nagpur santra. Indian J Hort. 2005; 62(2):181-183.

3. Biswas B, Ghosh SK, Ghosh B, Mitra SK. Effect of growth substances on fruit weight, size and quality of fruits cv. L-49. Indian Agricul. 1988; 32(4):245-248.

4. Canli FA, Mustafa P, Mustafa K. Effects of Pre-harvest Phyto growth regulator Sprays on Fruit Quality of 'Deveci' Pear (Pyrus communis L.). J of Appli. Bio. Sci. 2009; 3(1):81-84.

5. Chouksey S, Singh A, Thakur RS, Deshmukh R. Influence of gamma irradiation and benzyl adenine on keeping quality of custard apple fruits during storage. J Food Sci Techno. 2013; 50(5):934-941.

6. Drew P, Beniwal VS, Singh P. Papaya. Corn Publi. 1998; 59:66-8

7. Gaudence N, Janet CK, Everlyn MO, George OA, Fredah KR. Evaluation of the morphological and quality characteristics of new papaya hybrid lines in Kenya. African J of Biotech. 2019; 18(2):58-67.

8. Gomez KA, Gomez AA. Statistical procedures for Agricultural Research. $2^{\text {nd }}$ Ed. John Willey and Sons, New York, 1984.

9. Hajam MA, Hassan GI, Bhat TA, Bhat IA, Rather AM, Parray EA et al. Understanding phyto growth regulators, their interplay: For nursery establishment in fruits. Internatonal J. of Chemi. Studies. 2017; 5(5):905-910.

10. Hazarika TK, Balsri DS, Mandal D, Nautiyal BP, Shukla AC. Effect of phyto growth regulators on growth, yield and quality of tissue cultured papaya (Carica papaya) cv. Red lady. Indian J of Agri. Sci. 2016; 86(3):404-8.

11. Hetram. Effect of plant growth regulators on growth, yield and quality cv. Red Lady under Net House.2017.M.Sc. Thesis: Department of Fruit Science,Indira Gandhi Krishi Vishwavidyalaya,Raipur. Retrieved at http://krishikosh.egranth.ac.in/handle/1/ 5810041125

12. Hota D, Karna AK, Behera SD and Toppo P. NATCA a Potential Bio-Regulator for Fruit Production: A Review. Bull. Env. Pharmacol. Life Sci., 2019.Vol 8 [Suppl. 1]: S1-S4

13. Hota D, Sharma DP and Bhoyar MG. Analysis of vegetative growth by spraying of forchlorfenuron and $\mathrm{N}$ acetyl thiazolidine 4-carboxylic acid on of apricot (Prunus armeniaca L.) cv. New Castle. International Journal of Chemical Studies. 2017a. 5(5): 2182-2185

14. Hota D, Sharma DP and Sahoo T. Effect of Forchlorfenuron and N-acetyl Thiazolidine 4-carboxylic Acid on Chemical Parameter of Apricot (Prunus armeniaca L.) cv. New Castle. Current Journal of Applied Science and Technology. 2018. 31(1): 1-6.
15. Hota D, Sharma DP and Sharma N. Effect of Forchlorfenuron and N-Acetyl Thiazolidine 4-Carboxylic Acid on vegetative growth and fruit set of Apricot (Prunus armeniaca L.) cv. New Castle. Journal of Pharmacognosy and Phytochemistry. 2017b. 6(2): 279282

16. Hota D, Sharma DP and Singh N. Effect of Forchlorfenuron and N-Acetyl Thiazolidine 4-Carboxylic Acid on Fruit Drop of Apricot (Prunus armeniaca L.) cv. New Castle. International Journal of Pure \& Applied Bioscience. 2017c. 5(5):1123-1127

17. Hota D, Sharma DP, Prasad H and Chauhan A. Effect of Forchlorfenuron and N-Acetyl Thiazolidine 4-Carboxylic Acid on physico-chemical parameter of Apricot (Prunus armeniaca L.) cv. New Castle. Bulletin of Environment, Pharmacology and Life Sciences. 2017f. 6(5): 224-228

18. Hota D, Sharma DP, Sharma N, Mishra G, Solanki SPS and Priyadarshi V. Effect of Forchlorfenuron and NAcetyl Thiazolidine 4-Carboxylic Acid on Size and Yield of Apricot (Prunus armeniaca L.) cv. New Castle. International Journal of Current Microbiology and Applied Sciences. 2017d. 6(9): 1852-1860.

19. Hota D, Sharma DP, Sharma S and Singh N. Effect of Forchlorfenuron and N-Acetyl Thiazolidine 4-Carboxylic Acid on Physical Parameter of Apricot (Prunus armeniaca L.) cv. New Castle. Chemical Science Review and Letters. 2017e. 6(24): 2408-2412

20. Jain MC, Dashora LK. Effect of phyto growth regulators on physic-chemical characters and yield of guava cv. Sardar under high density planting system. Indian J. of Horti. 2011; 68:259-261.

21. Priyadarshi V, Hota D and Karna AK. Effect of growth regulators and micronutrients spray on chemical parameter of litchi (Litchi chinensis Sonn.) cv. Calcuttia. International journal of economic plants. 2018b. 5(3):99103

22. Priyadarshi V, Hota D, Solanki SPS and Singh N. Effect of growth regulators and micronutrients on yield attributing character of litchi (Litchi chinensis Sonn.) cv. Calcuttia. In: Singh J, Nigam R, Hasan W, Kumar A and Singh H. Advances in horticultural crops. Weser Books. Germany. pp- 269-277. 2018a.ISBN: 978-3-96492-079-9

23. Priyadarshi V, Mehta K, Hota D, Mishra G and Jogur A. Effect of growth regulators and micronutrients spray on vegetative growth of litchi (Litchi chinensis Sonn.) cv. Calcuttia. Agriculture Update. 2017.12(TECHSEAR-3): 707-712.

24. Radha T, Mathew L. Fruit Crops. New India Publishing Agency, New Delhi. 2007, 79.

25. Ranganna S. Hand Book of Analysis and Quality control for Fruit and Vegetable Product. Tata Mc-Graw Hill pub., New Delhi, 1997.http://www.chemijournal.com

26. Singh A, Singh JN. Effect of biofertilizers and bioregulators on growth, yield and nutrient status of strawberry cv. Sweet Charlie. Indian J of Horti. 2009; 66:220-4.

27. Vagadia P, Senapati A, Tank R, Mayani J, Koyani B. Evaluation of Physico-chemical and organoleptic quality of Papaya cv. Taiwan and Banana cv. Grand naine based mixed fruit bar during storage.International $\mathrm{J}$ of Agril Enviro. And Biotech. 2016; 9(4):541-544.

28. Yadav S, Bhatia SK, Godara RK, Rana GS. Effect of growth regulators on the yield and quality of winter season fruits cv. L-49. Haryana J Horti. Sci. 2001; 30:12. 